\title{
THE CONSTRUCTION AND EVALUATION OF A NORMATIVE LEARNING STYLE PREFERENCE QUESTIONNAIRE
}

\author{
MJ VILJOEN \\ JM SCHEPERS \\ K VAN ZYL \\ Department of Human Resource Management \\ Rand Afrikaans University
}

\begin{abstract}
Various authors have indicated the need for and value of identifying the learning style preferences of individual learners. Similar needs have been voiced in the South African context. The focal point of this study was the development of a normative instrument for predicting the preferred learning styles of individuals. Secondary aims were to determine whether there are differences between groups formed on the basis of gender, academic qualifications and functional disciplines as far as their learning style preferences are concerned. Based on a review of the literature and an existing questionnaire, namely the Learning Style Inventory (LSI 85), the Learning Style Preference Questionnaire (LSPQ) consisting of 136 items was developed and administered to respondents $(\mathrm{N}=542)$ in a large organisation. The LSPQ was subjected to a principal factor analysis and six factors were obtained. The six factors were rotated to simple structure by means of the Direct Oblimin procedure. The matrix of intercorrelations of the six factors was subjected to a second-order factor analysis and yielded a single factor. Six scales were constructed corresponding to the six factors. These scales were subjected to item analysis and yielded reliability coefficients that ranged from 0,809 to 0,939 according to Cronbach's coefficient alpha. The implications of the findings are discussed.
\end{abstract}

\section{OPSOMMING}

Verskeie outeurs het na die behoefte aan asook die waarde van identifikasie van leerstylvoorkeure van individuele leerders verwys. Soortgelyke behoeftes is ook in Suid-Afrikaanse verband geopper. Die fokus van hierdie studie was die ontwikkeling van 'n normatiewe instrument om die leerstylvoorkeure van individue te meet. Sekondêre doelwitte was om te bepaal of daar verskille tussen groepe is wat saamgestel is op grond van geslag, akademiese kwalifikasies en funksionele dissiplines wat hul leerstylvoorkeure betref. Gegrond op 'n oorsig van die literatuur en 'n bestaande vraelys, te wete die "Learning Style Inventory" (LSI 85), is die "Learning Style Preference Questionnaire" (LSPQ), bestaande uit 136 items, gekonstrueer en op 542 respondente in'n groot organisasie toegepas. Die LSPQ is aan 'n hooffaktorontleding onderwerp en ses faktore is verkry. Die ses faktore is deur middel van die Direct Oblimin-prosedure na eenvoudige struktuur geroteer. Die interkorrelasiematriks van die ses faktore is aan 'n tweedeordefaktorontleding onderwerp en het ' $\mathrm{n}$ enkelfaktor opgelewer. Daarna is ses skale gekonstrueer wat met die ses faktore ooreenstem. Hierdie skale is aan itemontleding onderwerp, en het betroubaarheidskoëffisiente wat wissel van 0,809 tot 0,939, volgens Cronbach se alfa-koëffisient, opgelewer. Die implikasies van die bevindinge is bespreek.

There has been a very strong interest by business in the concept of learning organisations and the capabilities required to build learning organisations. A learning organisation is defined as an organisation continuously transforming through the acquisiti on, processing and dissemination of knowledge about markets, products, technology, and business processes (Ellinger, Watkins \& Bostrom, 1999; Senge, Roberts, Ross, Smith, \& Kleiner, 1994). Learning is seen to be a key to survival in a rapidly changing world, requiring organisations to be faster and more effective in the way they learn (Prokesch, 1997; Senge, Kleiner, Roberts, Ross, Roth, \& Smith, 1999). A learning organisation needs to reflect a learning approach implicitly or explicitly in its vision, strategy and values to ensure that all employees have a shared focus (Abernathy, 1999; Pedler \& Aspinwall, 1998; Senge et al., 1999) In practice this requires an understanding of how the organisation, i.e. the individuals and teams in the organisation acquire, share and utilise knowledge (Dibella, Nevis \& Gould, 1996).

A true learning organisation intentionally makes use of individual and team learning (Dubois, 1993; Pedler \& Aspinwall, 1998; Senge et al., 1999). What really matters is an understanding of how individuals learn, what their preferred learning styles are and how their preferred style will contribute to their own and team learning (Pedler \& Aspinwall, 1998; Senge et al., 1994). Senge et al. (1994), supported by Stuart (1992) and Newstrom and Legnick-Hall (1991) suggested the use of a diagnostic instrument such as the Learning Style Inventory (LSI) of Kolb to help individuals gain an understanding of their preferred learning styles.

Kolb (1976, 1984) originated and pioneered the experiential learning theory (ELT), resulting in his learning style model

Requests for copies should be addressed to: T Groenewald, Technikon SA, Private Bag X6, Florida, 1710 and the LSI. Many other researchers such as Honey and Mumford (1982) and McCarthy (1987) were inspired by the work of Kolb, which made substantial contributions to the field of learning styles. The present study relies heavily on the work of Kolb because of its distinct contribution and frequent citation in the literature.

\section{Experiential learning and Kolb's model of learning styles} In the development of the ELT Kolb (1984) maintained that learning is a process involving the resolution of dialectical conflicts between opposing modes of dealing with the world, either through action and reflection or concrete or abstract interventions. He accredited his conceptualisation of the learning process to Jung's concept of style and to Lewin's theoretical model which describes individual differences in learning behaviour (Kolb, 1984; Loo, 1999; Verses, Sims \& Locklear, 1991).Kolb described learning as cyclical. He suggested two primary dimensions to the learning process, namely concrete experience (CE) as the polar opposite of abstract conceptualisation (AC), and reflective observation (RO) as the polar opposite of active experimentation (AE). These polar extremes are integrated into a four-stage cycle of learning ranging from perceiving and experiencing events (CE), to reflecting on experiences from different perspectives (RO), constructing theories which integrate observation (AC), actively using theories to make decisions, and solving problems (AE) (Kolb, 1984; Loo, 1999; Willcoxson \& Prosser, 1996).

Based on the ELT and the four-stage model of learning, the LSI was developed by Kolb to assess an individual's learning style preferences (Kolb, 1995; Verses et al., 1991). The LSI, a self-administered questionnaire, consists of 12 statements followed by four word endings corresponding to the four learning orientations (Geiger, Boyle \& Pinto, 1992; Kolb, 1995). Respondents are required to rank the four word endings for each set of 12 statements according to how well 
the word endings characterise their learning orientation (Allison \& Hayes, 1988; Kolb, 1995). This methodology renders the LSI (85) as an ipsative instrument.

Kolb defined the four learning styles according to the learner's preference for a particular phase of the learning cycle, namely converger emphasises abstract conceptualisation and active experimentation as the dominant learning mode; diverger emphasises concrete experience and reflective observation as the dominant learning mode; assimilator-emphasises abstract conceptualisation and reflective observation as the dominant learning mode; and accommodator - emphasises concrete experience and active experimentation as the dominant learning mode (Geiger et al., 1992; Kolb, 1984).

\section{Application of the LSI (85)}

The LSI (85) has been used to determine learning style preferences in cultural, social and cross-cultural studies (Chi-Ching \& Moi, 1994; Hong \& Suh, 1995), gender studies (Hickson, 1996; Wilson, 1996), academic qualification studies (Kolb, 1984) and functional discipline studies (Kolb, 1984; Smedley, 1987; Van Wyk, 1992) to mention but a few. For the purpose of this study it was decided to focus on the learning style preferences of three specific subgroups of the sample, namely gender groups, academic groups (academic qualifications of individuals) and functional disciplines (work areas of employees in an organisation).

\section{Learning styles and gender}

Several studies have been conducted to determine whether there are learning style differences between men and women. Severiens and Ten Dam (1997, p.80) found small but consistent gender differences in respect of the LSI (85). Men showed a stronger preference for the abstract conceptualisation learning mode than women. Men also seemed to be more interested in academic qualifications and their value. Women, by contrast, were more interested in the content and the value of learning.

In a study by Wilson (1996) the variance of preferred learning styles owing to gender, race and study course was examined. From the results it was evident that African-American women showed a much lower preference for active learning than men from the same group. Hickson (1996, p.65), in another study of gender and learning style preferences, found that women were more likely to be visual learners than men and that women preferred quiet learning environments, were more teachermotivated and more persistent.

\section{Learning styles and academic qualifications}

Early educational experiences shape individual learning styles (Kolb, 1984). Although the early years of education are for the most part generic, there is an increasing specialisation that develops in earnest in high school. For those who continue on to tertiary institutions, this specialisation develops in greater depth in the undergraduate years (Kolb, 1984). Jonassen and Garabowski (1993) also found that students tend to enter a field of study that matches their respective learning styles from school. However, should there be no match, the tendency is to change their field of study or choose a career outside their field of study. The reason for this is that the young employee's job is usually a continuation of his/her qualification and a refinement of his/her specialised skills and knowledge (Kolb, 1984).

\section{Learning styles and functional disciplines}

According to Kolb (1984), employees practising different functional disciplines are inclined to prefer different learning styles. This is evident from the variations among their primary tasks, technology, products, criteria for academic excellence, productivity, learning methods, research methods and methods for recording and portraying knowledge. Over time, owing to exposure to a firm way of doing things and socialisation pressures, a homogeneous disciplinary culture develops, directing students towards a particular learning style (Kolb, 1984). Honey and Mumford (1995), Kolb (1984), Slaat, Lodewijks and Van der Saden (1999) and Willcoxson and Prosser (1996) support this notion and found in their respective studies that chemists, medical students, marketers, researchers, engineers, personnel and financial people are homogeneous in their learning style preferences. In South Africa, it was found that apprentices from the same trade (De Klerk, 1993), black teaching students from the same field (Van Wyk, 1992) and managers from the same disciplines (Heymans, 1988) tend to be more alike than different in their approach to learning.

\section{A critical look at the ELT and the LSI (85)}

From the literature it is clear that there are three schools of thought concerning the validity and reliability of the ELT and the LSI (85). At the one extreme researchers such as Freedman and Stumpf (1980) and Reynolds (1997) refer to the ELT and the LSI (85) as failures, displaying insufficient evidence of reliability and validity. At the other extreme, Ferrell (1983) and Loo (1999), amongst others, refer to the ELT and LSI (85) as well-established, with considerable attraction and interest for application. Somewhere in the middle, researchers such as Geiger et al. (1992) and Merritt and Marshall (1984) support the ELT and LSI (85) with reservations, suggesting some changes to enhance the validity and reliability of the LSI (85). Of course, this is not forgetting Kolb's own defence of the ELT and LSI (85). In his response to criticism by Freedman and Stumpf, Kolb (1981) stated that they inappropriately assessed the validity of the ELT by basing their judgement primarily on an analysis of the internal characteristics of the LSI, with only the most superficial review of research on the theory. Furthermore, he also stated that their criticism of the reliability and structure of the LSI represented misapplications of statistical assumptions of stability and independence to a theory based on variability and interdependence.

In spite of Kolb's defence, researchers continued to level three specific criticisms at the psychometric properties of the LSI. Firstly, factoring an ipsative correlation matrix produces an invalid factor solution. Secondly, the two dimensions of the LSI account for only some $21 \%$ of the total variance. Thirdly, testretest studies display a lack of stability, a finding that conflicts with the ELT's position that learning styles are a relatively stable and enduring characteristic of the learner (Cornwell \& Manfredo, 1994; Verses et al., 1991). Allison and Hayes (1988) also refer to the reliability of the two scales reported by Kolb. They found the reliability of the abstract-concrete dimension and the active-reflective dimension to be only 0,40 and 0,52 (Cronbach alpha). By contrast, Kolb (1995) reports a Cronbach alpha of 0,88 for the abstract-concrete dimension and 0,81 for the active-reflective dimension of his LSI (85).

Merrit and Marshall (1984) also report on the psychometric qualities of the LSI and stress the ipsative nature of the instrument, warning of the dangers of using it as a normative instrument. In their quest to find a normative instrument, they redesigned the LSI, using the same word list of the inventory, asking respondents to rate the degree to which each word ending was characteristic of their preferred learning style. The four response choices for each word were "characteristic", "somewhat characteristic", "somewhat uncharacteristic" and "uncharacteristic". The results of the study suggested that the normative form of the LSI was consistent with the learning style model proposed by Kolb. The factor structure demonstrated construct validity and a moderate level of concurrent validity was found (Merrit \& Marshall, 1984).

In a similar study Geiger et al. (1993) used a 7-point Likert scale ranging from "very much like me" to "not like me" and randomised the order of the 48 independent learning style statements of the LSI in an attempt to create a normative instrument. Their factor analysis did not support the existence of any bipolar dimensions but did support the four separate learning styles. In conclusion, Geiger et al. (1993) were of the opinion that their modified instrument gave a better assessment of the four separate learning abilities than the LSI (85).

\section{Problem statement}

The LSI (85) is an ipsative instrument and should be valued as such and applied in proper context. As an ipsative instrument, it has value when the focus is on a single individual's relative strengths in terms of his/her learning preferences. Its focus is 
intra-individual. Applied for this purpose, the LSI (85) is seen to be a useful instrument. However, the LSI (85) should not be used to compare individuals with one another. A normative instrument, i.e. an inter-individually focused instrument, is required for this purpose. On inspection of the original LSI (85) and adapted versions of it, several problems were identified.

It was found that some of the learning concepts in the 12 statements and four word endings of the LSI (85) are in need of simplification in certain cases. Multiple learning concepts were found to be grouped in the same word endings, causing possible confusion for the respondent. At face value it seems that there is a broader area of learning to be described than is covered by the LSI (85). The adapted questionnaires merely linked existing versions of the LSI (85) to a seven-point scale with little or no expansion of the existing questionnaire. A normative instrument, determining learning style preferences under local conditions, does not exist for South Africans.

This is problematic. There is a definite need to objectively determine the preferred ways of learning of individuals and teams in an organisation. This would assist in establishing a learning approach for an organisation and help the organisation become a true learning organisation. It would create a better understanding of how individuals and teams prefer to learn, matching learning style preferences and the training needs of individuals and teams with effective training methodology.

\section{The aims of the study are as follows:}

- To develop a new normative instrument for determining the learning style preferences of South Africans, in contrast to Kolb's ipsative instrument. The new instrument should also describe a broader field of learning than the four modes of Kolb.

- To determine whether there are any differences in respect of gender, academic qualifications and functional disciplines as far as learning style preferences are concerned.

\section{Hypotheses}

1. The vectors of means of men and women differ statistically significantly from one another in respect of their learning style preferences.

2. The vectors of means of the various academic groups differ statistically significantly from one another in respect of their learning style preferences.

3. The vectors of means of the various functional disciplines differ statistically significantly from one another in respect of their learning style preferences.

\section{METHOD}

\section{Sample}

The questionnaire was distributed to the entire population of 2099 members of a large organisation operating in the field of "fast-moving consumer goods". All the incumbents, from supervisory to executive management level, were included. This group was selected in view of the literacy level required to complete the questionnaire. Employees from all over the country were included in the target sample. Participants operating in diverse functional disciplines, such as production, marketing, sales, engineering and distribution, were included. A total of $542 \mathrm{com}-$ pleted questionnaires were returned. No information is available as to why only $25,82 \%$ responded. No evidence of bias in the sample could be detected from the results. The biographical background information of the participants is given in Table 1.

The ages of the participants range from 24 to 62 years. The sample indicates a greater response by the male respondents $(64,8 \%)$, with female respondents accounting for $35,2 \%$ of the sample. The majority of the respondents are White (403), with Blacks second (74), Coloureds next (43) and Asians/Indians last (18). The educational level of the sample varies from less than Grade 12 to post-graduate qualifications. The majority of the respondents have Grade 12, Technicon diploma and Bachelor's degree qualifications. Participants with qualifications less than Grade $12(\mathrm{~N}=15)$ were excluded from the analysis.

TABLE 1

BIOGRAPICAL INFORMATION OF THE RESPONDENTS

\begin{tabular}{|c|c|c|}
\hline 1. GENDER & FREQUENCY & PERCENTAGE \\
\hline $\begin{array}{l}\text { Male } \\
\text { Female } \\
\text { Total }\end{array}$ & $\begin{array}{l}351 \\
191 \\
542\end{array}$ & $\begin{array}{r}64,8 \% \\
35,2 \% \\
100,0 \%\end{array}$ \\
\hline \multicolumn{3}{|l|}{ 2. AGE 2462 years } \\
\hline 3. MARITAL STATUS & FREQUENCY & PERCENTAGE \\
\hline $\begin{array}{l}\text { Single } \\
\text { Married } \\
\text { Divorced } \\
\text { Widowed } \\
\text { Living together } \\
\text { Total }\end{array}$ & $\begin{array}{r}101 \\
360 \\
53 \\
2 \\
26 \\
542\end{array}$ & $\begin{array}{r}18,6 \% \\
66,4 \% \\
9,8 \% \\
0,4 \% \\
4,8 \% \\
100,0 \%\end{array}$ \\
\hline 4. ACADEMIC QUALIFICATIONS & FREQUENCY & PERCENTAGE \\
\hline $\begin{array}{l}\text { Less than GR } 12(\text { std10) } \\
\text { Grade } 12(\text { std } 10) \\
\text { Technikon diploma } \\
\text { Bachelor's degree } \\
\text { Post-graduate diploma/degree } \\
\text { Other } \\
\text { Total }\end{array}$ & $\begin{array}{r}15 \\
143 \\
145 \\
121 \\
104 \\
14 \\
542\end{array}$ & $\begin{array}{r}2,8 \% \\
26,4 \% \\
26,8 \% \\
22,3 \% \\
19,2 \% \\
2,6 \% \\
100,0 \%\end{array}$ \\
\hline 5. CULTURAL GROUP & FREQUENCY & PERCENTAGE \\
\hline $\begin{array}{l}\text { Asian/Indian } \\
\text { Black } \\
\text { Coloured } \\
\text { White } \\
\text { Unknown } \\
\text { Total }\end{array}$ & $\begin{array}{r}18 \\
74 \\
43 \\
403 \\
4 \\
542 \\
\end{array}$ & $\begin{array}{r}3,3 \% \\
13,7 \% \\
7,9 \% \\
74,4 \% \\
0,7 \% \\
100,0 \%\end{array}$ \\
\hline $\begin{array}{l}\text { 6. CURRENT FUNCTIONAL } \\
\text { DISCIPLINE IN WORK PLACE }\end{array}$ & FREQUENCY & PERCENTAGE \\
\hline $\begin{array}{l}\text { Distribution } \\
\text { Finance } \\
\text { Human Resources } \\
\text { Information Technology } \\
\text { Marketing } \\
\text { Production } \\
\text { Risk Control } \\
\text { Sales } \\
\text { Other } \\
\text { Unknown } \\
\text { Total }\end{array}$ & $\begin{array}{r}81 \\
80 \\
44 \\
19 \\
47 \\
165 \\
13 \\
68 \\
20 \\
5 \\
542\end{array}$ & $\begin{array}{r}14,9 \% \\
14,8 \% \\
8,1 \% \\
3,5 \% \\
8,7 \% \\
30,4 \% \\
2,4 \% \\
12,5 \% \\
3,7 \% \\
0,9 \% \\
100,0 \%\end{array}$ \\
\hline
\end{tabular}




\section{Measuring instruments}

For the purpose of this study, permission was granted by Kolb to use the LSI (85) as a basis for the research of learning style preferences under South African conditions. The rationale of Kolb's four learning modes, of namely concrete experience, reflective observation, abstract conceptualisation and active experimentation, was used as a guideline for the design of a new questionnaire. In the design, the fields of learning style descriptions were extended by adding new descriptions. Existing learning style descriptions that were found to be too complex were simplified and care was taken to ensure that each item consisted of only one learning style description to prevent any chance of confusion. The newly constructed Learning Style Preference Questionnaire (LSPQ) consists of 136 items. The items are formulated as questions linked to a 7point response scale ranging from 1 (not at all) to 7 (to a great extent). Biographical questions relating to the participant's personal and employment history were also included in the questionnaire. The initial form of the questionnaire was applied to a small group of individuals, representative of the target population. Comments on the degree of complexity, ambiguity and overlap of items were invited and considered in the construction of the final version of the questionnaire.

\section{Procedure}

The questionnaires were distributed to the participants via the company's intranet. In view of the number of questionnaires to be mailed, and the effect this could have on the company's network, special permission had to be obtained. Clear instructions were given as to the electronic completion and return of the questionnaires. All completed questionnaires received were stored electronically for future reference.

\section{RESULTS}

To determine the factor structure of the LSPQ a procedure developed by Schepers (1992) was followed. The 136 items of the LSPQ were intercorrelated and the eigenvalues of the unreduced intercorrelation matrix were calculated. Owing to limited space, the intercorrelation matrix $(136 \times 136)$ is not reproduced here. Thirty-six factors were postulated according to Kaiser's (eigenvaluesgreaterthanone) criterion (1961), and extracted by means of a principal factor analysis. The factor matrix obtained was rotated to simple structure by means of a varimax rotation. Next, subscores were formed for each of the factors by adding together the scores of items with substantial loadings $(>0,30)$ on a factor. The subscores were then intercorrelated and subjected to a principal factor analysis. Owing to limited space, the matrix of intercorrelations of the subscores $(36 \times 36)$ is not reproduced here

* The eigenvalues of the unreduced intercorrelation matrix are given in Table 2 .

TABLE 2

EIGENVALUES OF UNREDUCED INTERCORRELATION MATRIX

\begin{tabular}{|c|c|c|c|c|c|}
\hline ROOT & EIGENVALUE & PERCENTAGE OF VARIANCE & ROOT & EIGENVALUE & PERCENTAGE OF VARIANCE \\
\hline & 10,348 & 28,995 & 19 & 0,601 & 1,669 \\
\hline 1 & 2,342 & 6,507 & 20 & 0,589 & 1,637 \\
\hline 2 & 1,852 & 5,144 & 21 & 0,538 & 1,494 \\
\hline 3 & 1,679 & 4,664 & 22 & 0,518 & 1,439 \\
\hline 4 & 1,357 & 3,769 & 23 & 0,501 & 1,391 \\
\hline 5 & 1,187 & 3,297 & 24 & 0,481 & 1,335 \\
\hline 6 & 1,083 & 3,009 & 25 & 0,468 & 1,301 \\
\hline 7 & 1,022 & 2,838 & 26 & 0,453 & 1,258 \\
\hline 8 & 0,979 & 2,719 & 27 & 0,428 & 1,190 \\
\hline 9 & 0,946 & 2,628 & 28 & 0,408 & 1,133 \\
\hline 10 & 0,871 & 2,420 & 29 & 0,392 & 1,088 \\
\hline 11 & 0,803 & 2,230 & 30 & 0,366 & 1,016 \\
\hline 12 & 0,741 & 2,058 & 31 & 0,345 & 0,957 \\
\hline 13 & 0,734 & 2,039 & 32 & 0,318 & 0,882 \\
\hline 14 & 0,707 & 1,963 & 33 & 0,308 & 0,855 \\
\hline 15 & 0,693 & 1,925 & 34 & 0,262 & 0,728 \\
\hline 16 & 0,645 & 1,791 & 35 & 0,170 & 0,473 \\
\hline 17 & 0,618 & 1,716 & 36 & 0,158 & 0,440 \\
\hline 18 & & & Trace & 36,000 & \\
\hline
\end{tabular}

An inspection of Table 2 shows that there are eight eigenvalues greater than unity. Accordingly, eight factors were extracted and rotated to simple structure by means of the Direct Oblimin procedure. The rotated factor matrix is given in Table 3 .

From an inspection of this table it is clear that six of the factors obtained are well determined, with three or more significant loa- dings. Factors 4 and 5 are poorly determined and were excluded from the study. Factor 4 loads on only three items and factor 5 on six items. The intercorrelations between the factors are given at the end of the table. Next, the intercorrelation matrix of the six factors retained was subjected to a second-order factor analysis. This analysis yielded one factor only, as can be seen in Table 4. All calculations were done by means of the SPSS-Windows programme of SPSS - International.

TABLE 3

ROTATED FACTOR MATRIX OF THE LEARNING STYLES PREFERENCE QUESTIONNAIRE (DIRECT OBLIMIN ROTATION)

\begin{tabular}{|c|c|c|c|c|c|c|c|c|}
\hline VARIABLE & FACTOR 1 & FACTOR 2 & FACTOR 3 & FACTOR 4 & FACTOR 5 & FACTOR 6 & FACTOR 7 & FACTOR 8 \\
\hline Subtest 1 & 0,302 & $-0,040$ & 0,288 & $-0,132$ & 0,257 & $-0,587$ & 0,049 & $-0,060$ \\
\hline Subtest 2 & 0,223 & $-0,090$ & 0,187 & 0,020 & $-0,070$ & $-0,249$ & 0,553 & 0,009 \\
\hline Subtest 3 & 0,455 & $-0,030$ & 0,292 & $-0,133$ & 0,079 & $-0,252$ & 0,186 & $-0,040$ \\
\hline Subtest 4 & $-0,040$ & $-0,128$ & 0,421 & 0,317 & 0,095 & 0,088 & 0,251 & 0,115 \\
\hline Subtest 5 & 0,452 & $-0,163$ & 0,328 & 0,005 & $-0,142$ & 0,037 & 0,211 & 0,039 \\
\hline Subtest 6 & 0,013 & $-0,010$ & $-0,009$ & 0,305 & $-0,109$ & $-0,529$ & 0,087 & 0,019 \\
\hline Subtest 7 & 0,257 & $-0,264$ & 0,142 & 0,152 & 0,238 & $-0,080$ & 0,321 & 0,089 \\
\hline Subtest 8 & 0,008 & $-0,122$ & 0,611 & 0,125 & $-0,157$ & $-0,030$ & 0,122 & 0,026 \\
\hline Subtest 9 & 0,037 & 0,007 & 0,411 & $-0,090$ & 0,083 & $-0,380$ & 0,049 & 0,114 \\
\hline Subtest 10 & 0,201 & 0,416 & $-0,113$ & 0,187 & $-0,132$ & $-0,162$ & 0,024 & 0,057 \\
\hline Subtest 11 & $-0,030$ & 0,186 & 0,041 & 0,103 & $-0,010$ & $-0,007$ & 0,531 & $-0,080$ \\
\hline Subtest 12 & 0,108 & $-0,010$ & 0,332 & 0,092 & $-0,040$ & $-0,177$ & 0,359 & $-0,060$ \\
\hline Subtest 13 & 0,298 & $-0,070$ & 0,070 & $-0,106$ & 0,055 & $-0,326$ & $-0,080$ & 0,368 \\
\hline Subtest 14 & 0,393 & $-0,040$ & $-0,162$ & $-0,050$ & 0,115 & 0,061 & 0,385 & 0,246 \\
\hline Subtest 15 & 0,468 & $-0,124$ & $-0,060$ & $-0,060$ & $-0,050$ & $-0,060$ & 0,201 & 0,208 \\
\hline Subtest 16 & 0,101 & 0,836 & 0,076 & 0,643 & $-0,040$ & 0,030 & $-0,080$ & $-0,040$ \\
\hline Subtest 17 & 0,070 & 0,256 & 0,046 & 0,100 & 0,112 & $-0,008$ & 0,164 & 0,164 \\
\hline Subtest 18 & 0,611 & 0,085 & 0,028 & 0,055 & 0,016 & $-0,050$ & $-0,125$ & 0,030 \\
\hline Subtest 19 & 0,202 & 0,045 & 0,031 & 0,216 & 0,289 & $-0,139$ & 0,070 & 0,056 \\
\hline Subtest 20 & $-0,114$ & 0,020 & $-0,148$ & 0,299 & 0,147 & $-0,150$ & 0,318 & 0,186 \\
\hline Subtest 21 & 0,134 & $-0,010$ & $-0,080$ & $-0,040$ & 0,050 & $-0,050$ & 0,560 & 0,048 \\
\hline Subtest 22 & 0,191 & $-0,122$ & 0,053 & $-0,006$ & 0,390 & $-0,163$ & 0,224 & 0,013 \\
\hline Subtest 23 & 0,044 & 0,022 & 0,063 & 0,049 & $-0,480$ & $-0,208$ & 0,287 & 0,127 \\
\hline
\end{tabular}


TABLE 3 (continued)

ROTATED FACTOR MATRIX OF THE LEARNING STYLES PREFERENCE QUESTIONNAIRE (DIRECT OBLIMIN ROTATION)

\begin{tabular}{|c|c|c|c|c|c|c|c|c|}
\hline VARIABLE & FACTOR 1 & FACTOR 2 & FACTOR 3 & FACTOR 4 & FACTOR 5 & FACTOR 6 & FACTOR 7 & FACTOR 8 \\
\hline Subtest 24 & 0,151 & 0,144 & 0,017 & $-0,168$ & 0,201 & $-0,020$ & 0,094 & 0,413 \\
\hline Subtest 25 & 0,105 & 0,163 & $-0,213$ & 0,063 & 0,008 & $-0,324$ & 0,298 & 0,070 \\
\hline Subtest 26 & 0,134 & 0,014 & $-0,070$ & 0,064 & $-0,009$ & $-0,276$ & $-0,090$ & 0,276 \\
\hline Subtest 27 & 0,098 & 0,144 & 0,023 & 0,018 & $-0,002$ & 0,023 & 0,192 & 0,394 \\
\hline Subtest 28 & 0,053 & 0,137 & 0,567 & 0,006 & 0,048 & $-0,050$ & $-0,129$ & 0,040 \\
\hline Subtest 29 & 0,439 & 0,053 & 0,051 & 0,203 & 0,113 & 0,023 & 0,038 & $-0,080$ \\
\hline Subtest 30 & 0,030 & 0,060 & 0,053 & 0,002 & $-0,134$ & $-0,060$ & $-0,159$ & 0,577 \\
\hline Subtest 31 & $-0,040$ & 0,780 & 0,068 & $-0,020$ & $-0,007$ & 0,022 & 0,046 & 0,066 \\
\hline Subtest 32 & $-0,020$ & 0,098 & 0,107 & $-0,050$ & $-0,040$ & $-0,485$ & $-0,030$ & 0,109 \\
\hline Subtest 33 & 0,017 & 0,041 & 0,074 & 0,043 & 0,101 & $-0,309$ & 0,135 & 0,310 \\
\hline Subtest 34 & 0,069 & $-0,103$ & $-0,132$ & 0,067 & 0,145 & $-0,285$ & 0,402 & 0,023 \\
\hline Subtest 35 & $-0,040$ & $-0,116$ & 0,099 & 0,252 & 0,173 & $-0,080$ & $-0,020$ & 0,351 \\
\hline Subtest 36 & 0,095 & $-0,070$ & 0,126 & $-0,080$ & $-0,060$ & $-0,050$ & 0,534 & 0,142 \\
\hline \multicolumn{9}{|c|}{ MATRIX OF INTERCORRELATIONS OF FACTORS } \\
\hline & 1 & 2 & 3 & 4 & 5 & 6 & & \\
\hline 1 & 1,000 & 0,018 & 0,302 & $-0,473$ & 0,392 & 0,409 & & \\
\hline 2 & 0,018 & 1,000 & $-0,123$ & $-0,050$ & $-0,070$ & 0,189 & & \\
\hline 3 & 0,302 & $-0,123$ & 1,000 & $-0,254$ & 0,152 & 0,193 & & \\
\hline 4 & $-0,473$ & $-0,050$ & $-0,254$ & $1,000-$ & 0,387 & $-0,482$ & & \\
\hline 5 & 0,392 & $-0,070$ & 0,152 & $-0,387$ & 1,000 & 0,297 & & \\
\hline 6 & 0,409 & 0,189 & 0,193 & $-0,482$ & 0,297 & 1,000 & & \\
\hline
\end{tabular}

Next, six scales were formed by allocating the items with substantial loadings $(>0,30)$ on a particular factor, to a scale. Each of the six scales was subjected to item analysis using the NP 50 programme of the National Institute for Personnel Research. The item statistics of Scale 1 are given in Table 5.

TABLE 4

SECOND-ORDER FACTOR MATRIX

\begin{tabular}{lcc} 
& FACTOR I & $\mathrm{h}^{2} \mathrm{j}$ \\
\hline Factor 1 & 0,860 & 0,739 \\
Factor 2 & 0,309 & 0,095 \\
Factor 3 & 0,644 & 0,414 \\
Factor 4 & $-0,879$ & 0,774 \\
Factor 5 & 0,808 & 0,653 \\
Factor 6 & 0,717 & 0,514 \\
\hline
\end{tabular}

Owing to limited space, only a summary of the item statistics of the other five scales will be given here. From an inspection of the items in Scale 1 it can be seen that respondents with high scores on Scale 1 learn through practical involvement in the learning situation, analysing detail. This conclusion was reached by inspecting the subtests of Scale 1

(Table 5). The subtests forming Scale 1 are Subtest 3 with 12 items (Q7B, Q13A, Q19A, Q19B, Q22B, Q25A, Q25B, Q39, Q40A Q40B, Q44, Q54), Subtest 5 with 5 items (Q1A, Q1B, Q2A, Q2B, Q14A), Subtest 14 with 4 items (Q11A, Q11B, Q23A, Q23B), Subtest 15 with 4 items (Q30A, Q30B, Q31A, Q31B), Subtest 18 with 2 items (Q5A, Q5B) and Subtest 29 with 3 items (Q3A, Q3B, Q7A). Items from this scale link learning to notions such as practical, basic, breaking things down into parts, analytical and thinking. The dominant subtest, Subtest 3, links learning to concepts such as reasoning things out, considering and dealing with ideas. In summary, this scale portrays learning through reasoning.

The summary statistics in respect of Scales 1 to 6 appear in Table 6 and a summary of the items included in the subtests of the scales appear in Table 7. From Table 6 it is clear that the mean of Scale 1 is 169,956 and the standard deviation is 18,305 . All 30 items were retained and the reliability according to Cronbach's coefficient alpha is 0,919 .

TABLE 5

ITEM STATISTICS IN RESPECT OF SCALE 1OF THE LEARNING STYLES PREFERENCE QUESTIONAIRE

\begin{tabular}{|c|c|c|c|c|c|}
\hline \multirow[t]{2}{*}{ ITEM } & \multirow[t]{2}{*}{ DESCRIPTION OF ITEM } & \multirow{2}{*}{$\begin{array}{c}\text { MEAN OF } \\
\text { ITEM } \\
\overline{\mathbf{X}}_{\mathrm{g}}\end{array}$} & \multirow{2}{*}{$\begin{array}{c}\text { STANDARD } \\
\text { DEVIATION } \\
\text { OF ITEM } \\
\text { sg }\end{array}$} & \multicolumn{2}{|c|}{$\begin{array}{l}\text { INDICES OF ITEM-TOTAL } \\
\text { RELIABILITY CORRELATION }\end{array}$} \\
\hline & & & & rgx sg & rgx \\
\hline 1a. & How often do you think about ideas while learning? & 5,288 & 1,273 & 0,722 & 0,567 \\
\hline $1 \mathrm{~b}$. & How effectively do you learn when you think about ideas? & 5,183 & 1,292 & 0,708 & 0,548 \\
\hline $2 \mathrm{a}$. & To what extent do you learn while doing things? & 5,828 & 1,140 & 0,517 & 0453 \\
\hline $2 \mathrm{~b}$. & How effectively do you learn while doing things? & 5,812 & 1,165 & 0,575 & 0,494 \\
\hline 3 a. & To what extent do you learn when you are emotionally involved in the situation? & 5,290 & 1,358 & 0,569 & 0,419 \\
\hline $3 \mathrm{~b}$. & How effectively do you learn when you are emotionally involved in the situation? & 5,185 & 1,351 & 0,550 & 0,407 \\
\hline 5a. & To what extent do you learn by first analysing and then generalising? & 5,212 & 1.090 & 0,569 & 0,522 \\
\hline $5 \mathrm{~b}$. & How effectively do you learn by first analysing and then generalising? & 5,266 & 1,161 & 0,768 & 0,584 \\
\hline 7a. & To what extent do you rely on logical thinking while learning? & 5,906 & 1,096 & 0,590 & 0,539 \\
\hline 7b. & How effectively do you learn when you rely on logical thinking? & 5,941 & 0,963 & 0,573 & 0,594 \\
\hline 11a. & To what extent do you learn by following a practical approach to matters? & 5,851 & 0,929 & 0,484 & 0,521 \\
\hline 11b. & How effectively do you learn by following a practical approach to matters? & 5,924 & 0,948 & 0,478 & 0,505 \\
\hline 13a. & To what extent do you tend to reason things out while learning? & 5,919 & 1,009 & 0,660 & 0,654 \\
\hline 14a. & How often do you try out things while learning? & 5,472 & 1,276 & 0,688 & 0,538 \\
\hline 19a. & To what extent do you try out things while learning? & 5,768 & 0,979 & 0,614 & 0,627 \\
\hline 19b. & How effectively do you learn by thinking? & 5,755 & 1,074 & 0,650 & 0,605 \\
\hline 22b. & How effectively do you learn by considering all aspects of an issue? & 5,755 & 1,074 & 0,650 & 0,605 \\
\hline $23 a$. & How important is it to understand the basic principles of an issue while learning? & 6,498 & 0,813 & 0,385 & 0,473 \\
\hline $23 \mathrm{~b}$. & How effectively do you learn when you understand the basic principles of an issue? & 6,489 & 0,771 & 0,379 & 0,492 \\
\hline $25 \mathrm{a}$. & To what extent do you like to analyse things while learning? & 5,851 & 0,991 & 0,681 & 0,687 \\
\hline $25 \mathrm{~b}$. & How effectively do you learn when you analyse things? & 5,956 & 0,958 & 0,664 & 0,693 \\
\hline $30 \mathrm{a}$. & To what extent do you like breaking things down into parts while learning? & 5,581 & 1,211 & 0,656 & 0,541 \\
\hline $30 \mathrm{~b}$. & How effectively do you learn when you break things down into parts? & 5,747 & 1,156 & 0,614 & 0,531 \\
\hline 31 a. & To what extent do you take responsibility for your actions while learning? & 5,998 & 0,991 & 0,569 & 0,574 \\
\hline $31 \mathrm{~b}$. & How effectively do you learn when taking responsibility for your actions? & 6,070 & 0,976 & 0,619 & 0,634 \\
\hline \multirow[t]{2}{*}{39.} & How readily would you change your style from learning through feelings to & & & & \\
\hline & learning through thinking if required? & 5,190 & 1,354 & 0,670 & 0,495 \\
\hline $40 \mathrm{a}$. & To what extent do you like dealing with ideas while learning? & 5,627 & 1,075 & 0,804 & 0,748 \\
\hline 40b. & How effectively do you learn by dealing with ideas? & 5,641 & 1,096 & 0,782 & 0,713 \\
\hline 44. & How readily would you change your style from learning through watching to learning & & & & \\
\hline \multirow{2}{*}{54.} & through thinking if required & 5,100 & 1,335 & 0,615 & 0,461 \\
\hline & $\begin{array}{l}\text { How readily would you change your style from learning through doing things to } \\
\text { learning through thinking if required? }\end{array}$ & 4,862 & 1,313 & 0,550 & 0,419 \\
\hline
\end{tabular}

$\star$ The relevant matrices are available from the author on request 
TABLE 6

MEANS AND STANDARD DEVIATIONS OF THE ITEM STATISTICS OF THE SIX SCALES OF THE LSPQ

\begin{tabular}{|c|c|c|c|c|c|c|}
\hline \multirow[t]{13}{*}{ SCALE } & & & $\begin{array}{l}\text { MEAN OF } \\
\text { ITEMS }\end{array}$ & $\begin{array}{l}\text { STANDARD } \\
\text { DEVIATION } \\
\text { OF ITEMS }\end{array}$ & $\begin{array}{c}\text { INDICES } \\
\text { OF RELIABILITY } \\
r_{\mathrm{gx}} s_{\mathrm{g}}\end{array}$ & $\begin{array}{c}\text { ITEM-TOTAL } \\
\text { CORRELATION } \\
r_{\mathrm{gx}}\end{array}$ \\
\hline & SCALE 1 & Mean & 5,665 & 1,107 & 0,610 & 0,556 \\
\hline & & Standard Deviation & 0,394 & 0,162 & 0,099 & 0,090 \\
\hline & SCALE 2 & Mean & 4,299 & 1,498 & 0,948 & 0,625 \\
\hline & & Standard Deviation & 0,626 & 0,177 & 0,217 & 0,084 \\
\hline & SCALE 3 & Mean & 4,913 & 1,305 & 0,785 & 0,601 \\
\hline & & Standard Deviation & 0,343 & 0,149 & 0,130 & 0,058 \\
\hline & SCALE 4 & Mean & 5,532 & 1,097 & 0,659 & 0,600 \\
\hline & & Standard Deviation & 0,218 & 0,101 & 0,110 & 0,081 \\
\hline & SCALE 5 & Mean & 5,863 & 1,003 & 0,590 & 0,594 \\
\hline & & Standard Deviation & 0,280 & 0,135 & 0,073 & 0,077 \\
\hline & SCALE 6 & Mean & 5,367 & 1,148 & 0,677 & 0,592 \\
\hline & & Standard Deviation & 0,351 & 0,107 & 0,065 & 0,058 \\
\hline
\end{tabular}

DESCRIPTIVE STATISTICS OF THE SIX SCALES OF THE LSPQ

\begin{tabular}{lrrr}
\hline & SCALE 1 & SCALE 2 & SCALE 3 \\
\hline Mean of Scale & 169,956 & 38,692 & 78,613 \\
Standard Deviation & 18,305 & 13 & 138,290 \\
Cronbach Alpha & 0,919 & 8,534 & 16,467 \\
Number of Items & 30 & 0,809 & 9 \\
\hline
\end{tabular}

TABLE 7

ITEMS INCLUDED IN THE SUBTESTS OF THESIX SCALES OF THE LSPQ

\begin{tabular}{l}
\hline Items included in subtests of Scale 1 \\
\hline Subtest 3: 7b, 13a, 19a, 19b, 22b, 25a, \\
25b, 39, 40a, 40b, 44, 54 \\
Subtest 5: 1a, 1b, 2a, 2b, 14a \\
Subtest 14: 11a, 11b, 23a, 23b \\
Subtest 15: 30a, 30b, 31a, 31b \\
Subtest 18: 5a, 5b \\
Subtest 29: 3a, 3b, 7a \\
\hline
\end{tabular}

Items included in subtests of Scale 4

Subtest 1: 22a, 35a, 35b, 50a, 50b, 53a,

$53 \mathrm{~b}, 55 \mathrm{a}, 55 \mathrm{~b}, 60 \mathrm{a}, 60 \mathrm{~b}, 67 \mathrm{a}$,

$67 \mathrm{~b}, 70 \mathrm{a}, 70 \mathrm{~b}$

Subtest 6: 72a, 72b, 73a, 73b

Subtest 25: 52a, 52b

Subtest 26: $10 \mathrm{a}, 10 \mathrm{~b}$

Subtest 32: 58a, 58b

\begin{tabular}{l} 
Items included in subtests of Scale 2 \\
\hline Subtest 10: 4a, 4b, 18, 29, 34 \\
Subtest 17: 63a, 63b, \\
Subtest 31: 16a, 16b
\end{tabular}

Items included in subtests of Scale 3

Subtest 4: 15a, 15b, 21a, 21b, 45a, 45b

Subtest 8: 46a, 46b, 74a, 74b

Subtest 9: 48a, 48b, 69a, 69b

Subtest 28: 65a, 65b

\begin{tabular}{l}
\hline \\
\hline Items included in subtests of Scale 5 \\
\hline Subtest 2: 9a, 9b, 13b, 14b, 42a, 42b, \\
51b, 56a, 56b, 62a, 62b, 68a, \\
68b, 71a, 71b \\
Subtest 7: 36a, 36b, 37a, 37b \\
Subtest 11: 49, 59, 64 \\
Subtest 12: 51a, 61a, 61b \\
Subtest 20: 41a, 41b \\
Subtest 21: 26a, 26b \\
Subtest 34: 57a, 57b \\
Subtest 36: 20a, 20b \\
\hline
\end{tabular}

\begin{tabular}{l}
\hline Items included in subtests of Scale 6 \\
\hline Subtest 13: 33a, 33b, 38a, 38b \\
Subtest 24: 17a, 17b \\
Subtest 27: 8a, 8b \\
\hline
\end{tabular}

An inspection of Table 6 shows that the mean of Scale 2 is 38,692 and the standard deviation is 8,534. All 9 items were retained and the reliability according to Cronbach's coefficient alpha is 0,809 . It is evident from an inspection of the items in Scale 2 that respondents with high scores on Scale 2 learn through watching and observing, internalising the learning situation and content. Items from Scale 2 typically refer to notions such as watching and observing and reviewing processes. Subtests 10,17 and 31 form the basis of this scale, with no subtest dominating. In summary, this scale measures learning through observation.

From Table 6 it is clear that the mean of Scale 3 is 78,613 and the standard deviation is 12,568. All 16 items were retained and the reliability according to Cronbach's coefficient alpha is 0,881 . An inspection of the items in Scale 3 shows that people with high scores on Scale 3 learn through exploring new and untested terrain. Items from Scale 3 typically refer to notions such as risk-taking, breaking rules, trying the new, relying on gut feelings, exploring and testing alternatives. Subtests 4, 8, 9 and 28 form the basis of this scale, with no subtest dominating. In summary, this scale measures learning through exploring alternatives.

The mean of Scale 4 is 138,290 and the standard deviation is 16,467, as shown in Table 6. All 25 items were retained and the reliability according to Cronbach's coefficient alpha is 0,925 . An inspection of the items contained in Scale 4 indicates that respondents with high scores on Scale 4 learn by establishing a broad base, including all aspects of the learning situation. Items from Scale 4 typically refer to notions such as underlying theory, basic assumptions, gaining an overall view and considering all aspects of the learning situation. Subtests 1, 6,
25, 26 and 32 form the basis of this scale, with Subtest 1 being the dominant subtest. In summary, this scale portrays learning through relying on a sound basis of fact and theory.

An inspection of Table 6 shows that the mean of Scale 5 is 193,487 and the standard deviation is 19,450. All 33 items were retained and the reliability according to Cronbach's coefficient alpha is 0,939. It is clear from an inspection of the items in Scale 5 that respondents with high scores on Scale 5 learn through active involvement in the learning situation, responding spontaneously. Items from Scale 5 typically refer to notions such as spontaneous learning, practising new skills, trying things out, seeing results and being active in learning, suggesting a continuous involvement in learning. Subtests 2, 7, 11, 12, 20, 21, 34 and 36 form the basis of this scale, with Subtest 2 being the dominant subtest. In summary, this scale portrays learning through practising new skills.

From Table 6 it is clear that the mean of Scale 6 is 75,138 and the standard deviation is 9,471 . All 14 items were retained and the reliability according to Cronbach's coefficient alpha is 0,854 . From an inspection of the items in Scale 6 it is evident that people with high scores on Scale 6 learn through considering current and future situations and carefully exercising options. Items from Scale 6 typically refer to notions such as considering all facts, being open to conviction, relying on facts and taking time before acting, suggesting that learning takes place by focusing on current events projected onto future events. Subtests 13, 24, 27, 30, 33 and 35 form the basis of this scale, with no subtest dominating. In summary, this scale portrays learning through considering all facts at hand.

From the six scales it appears that people do learn in more 
TABLE 8

HOTELLING T2 : COMPARISON OF THE MEANS OF MEN AND WOMEN IN RESPECT OF THE SIX SCALESOF THE LSPQ

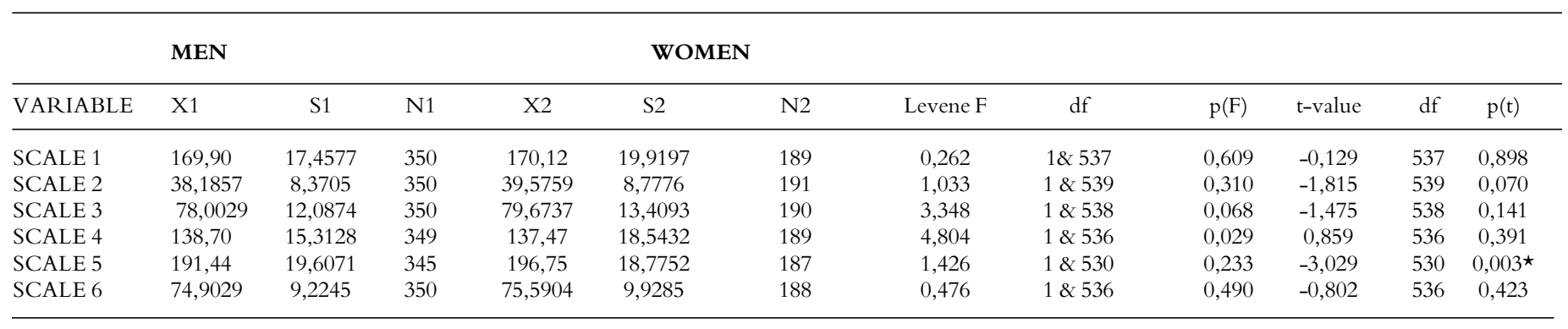

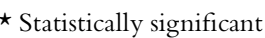

Hotelling $\mathrm{T}^{2}=0,067 d f=6$ and 514

$F=5,707 p=0,001$ (Significant)

diverse ways than is reflected by the original instrument of Kolb. The LSPQ not only included and broadened the existing descriptions of learning by Kolb, but also added deeper levels of learning outside the existing descriptions.

An ancillary aim of this study was to determine whether there are statistically significant differences in the means of the subgroups of the sample in respect of gender, academic qualifications and functional disciplines as far as learning style preferences are concerned. From Table 8 it is apparent that there are statistically significantly differences between the vectors of means of the men and women (Hotelling's T2 $=0,067 ; F(6$, $514)=1,426 ; p<0,001)$. However, only the difference in respect of Scale 5 is statistically significant, the mean score of the women being higher than that of the men. Thus there is partial support for hypothesis 1 .

The results of the multiple analysis of variance (MANOVA) for the four academic groups in respect of the six scales are shown in Table 9.

From an inspection of the table it appears that Wilks' coefficient lambda is equal to 0,834 with an associated $F$ (18 and $1411,9)=5,190 ; p<0,001$. The overall null hypothesis is there-

TABLE 9

MANOVA AND ASSOCIATED ANOVAS: COMPARISON OF THE MEANS OF THE VARIOUS “ACADEMIC GROUPS” IN RESPECT OF THE SIX SCALES OF THE LSPQ

\begin{tabular}{cccc}
\hline $\begin{array}{c}\text { WILKS' } \\
\text { COEFFICIENT } \\
\text { LAMBDA }\end{array}$ & $\mathrm{F}$ & $\mathrm{df}$ & $\mathrm{p}$ \\
\hline 0,834 & 5,190 & $18,1411,9$ & 0,001 \\
& & & \\
SCALE 1 & 4,175 & 3,521 & $0,006^{\star}$ \\
SCALE 2 & 12,055 & 3,523 & $0,001^{\star}$ \\
SCALE 3 & 4,127 & 3,522 & $0,007^{\star}$ \\
SCALE 4 & 2,514 & 3,520 & 0,058 \\
SCALE 5 & 0,043 & 3,515 & 0,988 \\
SCALE 6 & 2,543 & 3,520 & 0,056 \\
\hline
\end{tabular}

fore rejected. From the one-way analyses of variance (ANOVA), it appears that there are statistically significant differences in the means of Scale 1, F (3 and 521) = 4,175; $p=0,006$; Scale 2, $F(3$ and 523$)=12,055 ; p<0,001$ and Scale $3, F$ (3 and $522)=4,127 ; p=0,007$. Next, multiple comparisons were done using Scheffe's technique if the variances did not differ and Dunnett's technique if the variances differed. Dunnett's posthoc multiple comparisons technique was used to determine which academic groups differed from one another in respect of Scale 1. The results show that the group with Grade 12 or equivalent qualifications differ statistically significantly from the group with technicon diplomas and the group with postgraduate degrees/diplomas. The Grade 12 mean scores were lower, as shown in Table 10.

Scheffés post-hoc multiple comparisons technique was used to determine which academic groups differed from one another in respect of Scales 2 and 3. The results for Scale 2 show that the group with Grade 12 or equivalent qualifications differs statistically significantly from the groups with bachelor's degrees and post-graduate degrees/diplomas, their mean scores being higher. Similarly, the group with technicon diplomas differs statistically significantly from the group with bachelor's degrees and post-graduate degrees/diplomas, their mean scores being higher, as shown in Table 11. The results for Scale 3 show that the group with Grade 12 or equivalent qualifications differs statistically significantly from the group with post-graduate degrees/diplomas, their mean scores being lower, as shown in Table 11. There are no differences in respect of the other scales. Hypothesis 2 is therefore only partially supported.

The results of the MANOVA for the eight groupings of functional disciplines in respect of the six scales of the LSPQ are shown in Table 12.

An inspection of Table 12 shows that Wilks' coefficient lambda is equal to $0,831(F(48,2497)=1,978 ; p<0,001)$. The overall null hypothesis is therefore rejected. From the ANOVAs, it is apparent that there are statistically significantly differences in the means of Scale $2(F(8,578)=3,178 ; p=0,002)$, Scale 3 $(F(8,526)=2,013 ; p=0,043)$ and Scale $6(F(8,524)=2,882$;

TABLE 10

DUNNETT'S POST-HOC MULTIPLE COMPARISONS: COMPARISON OF THE MEANS OF THE VARIOUS “ACADEMIC GROUPS”IN RESPECT OF SCALE 1 OF THE LSPQ

\begin{tabular}{|c|c|c|c|c|c|c|c|c|c|}
\hline \multirow[t]{2}{*}{ VARIABLE } & \multicolumn{6}{|c|}{ MEANS } & \multicolumn{3}{|c|}{ GROUPS } \\
\hline & $\begin{array}{c}1 \\
\text { GRADE } 12 \text { OR } \\
\text { EQUIVALENT } \\
\mathrm{N}=156\end{array}$ & $\begin{array}{c}2 \\
\text { TECHNICON } \\
\text { DIPLOMA } \\
\mathrm{N}=144\end{array}$ & $\begin{array}{c}3 \\
\text { BACHELOR'S } \\
\text { DEGREE } \\
\mathrm{N}=121\end{array}$ & $\begin{array}{c}4 \\
\text { POST GRA- } \\
\text { DUATE } \\
\text { DEGREE/ } \\
\text { DIPLOMA } \\
\mathrm{N}=104\end{array}$ & $1 / 2$ & $1 / 3$ & $1 / 4$ & $2 / 3$ & $2 / 4$ \\
\hline SCALE 1 & 165,63 & 171,47 & 170,45 & 172,93 & $\star$ & & $\star$ & & \\
\hline
\end{tabular}


TABLE 11

SCHEFFÉ'S POST-HOC MULTIPLE COMPARISONS: COMPARISON OF THE MEANS OF THE VARIOUS “ACADEMIC GROUPS” IN RESPECT OF SCALES 2,3,4,5 AND 6 OF THE LAPQ

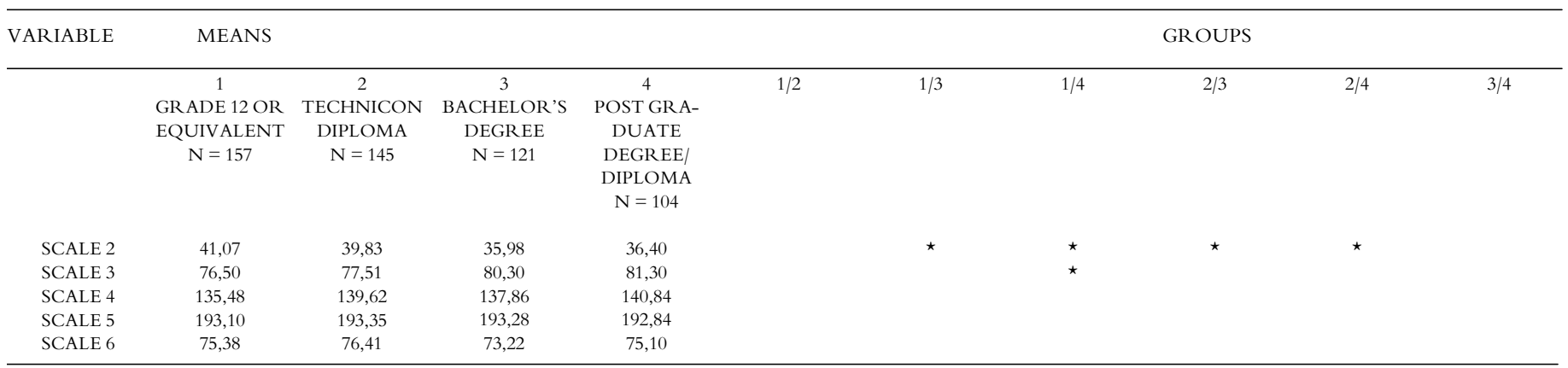

$\star \mathrm{P}=0,05$

TABLE 12

MANOVA AND ASSOCIATED ANOVAS: COMPARISON OF THE MEANS OF THE VARIOUS “FUNCTIONAL DISCIPLINES" IN RESPECT OF THE SIX SCALES OF THE LSPQ

\begin{tabular}{cccc}
\hline $\begin{array}{c}\text { WILKS' COEFFICIENT } \\
\text { LAMBDA }\end{array}$ & F & df & p \\
\hline 0,831 & 1,978 & 48,2479 & $0,001^{\star}$ \\
& & & \\
SCALE 1 & 1,660 & 8,525 & 0,106 \\
SCALE 2 & 3,178 & 8,527 & $0,002^{\star}$ \\
SCALE 3 & 2,013 & 8,526 & $0,043^{\star}$ \\
SCALE 4 & 1,763 & 8,524 & 0,082 \\
SCALE 5 & 1,066 & 8,519 & 0,386 \\
SCALE 6 & 2,882 & 8,524 & $0,004^{\star}$ \\
\hline
\end{tabular}

TABLE 13

SCHEFFE'S POST-HOC MULTIPLE COMPARISONS: COMPARISON OF THE MEANS OF VARIOUS "FUNCTIONAL DISCIPLINES" IN RESPECT OF SCALES 1,2,4 AND 5 OF THE LSPQ

\begin{tabular}{|c|c|c|c|c|c|}
\hline & VARIABLE & SCALE 1 & SCALE 2 & SCALE 4 & SCALE 5 \\
\hline $\begin{array}{l}\text { Z } \\
\sum \\
\sum \\
\Sigma\end{array}$ & $\begin{array}{l}\text { 1- HR } \\
\text { 2 DISTRIBUTION } \\
\text { 3- FINANCE } \\
\text { 4- INF SERVICES } \\
\text { 5- MAR KETING } \\
\text { 6- PRODUCTION } \\
\text { 7-RISK CONTROL } \\
\text { 8- SALES } \\
1 / 2 \\
1 / 3 \\
1 / 4 \\
1 / 5 \\
1 / 6 \\
1 / 7 \\
1 / 8 \\
2 / 3 \\
2 / 4 \\
2 / 5 \\
2 / 6 \\
2 / 7 \\
2 / 8 \\
3 / 4 \\
3 / 5 \\
3 / 6 \\
3 / 7 \\
3 / 8 \\
4 / 5 \\
4 / 6 \\
4 / 7 \\
4 / 8 \\
5 / 6 \\
5 / 7 \\
5 / 8 \\
6 / 7 \\
6 / 8 \\
7 / 8\end{array}$ & $\begin{array}{l}170,63 \\
172,73 \\
169,19 \\
174,53 \\
163,36 \\
170,37 \\
160,77 \\
170,75\end{array}$ & $\begin{array}{l}35,09 \\
39,28 \\
38,04 \\
38,26 \\
38,60 \\
38,12 \\
39,92 \\
42,63\end{array}$ & $\begin{array}{l}-91,93 \\
-93,94 \\
-91,44 \\
-93,58 \\
-87,34 \\
-92,73 \\
-91,46 \\
-97,84\end{array}$ & $\begin{array}{l}190,81 \\
190,01 \\
187,18 \\
186,47 \\
182,53 \\
186,60 \\
182,38 \\
190,04\end{array}$ \\
\hline
\end{tabular}

$p=0,004)$. Next, Scheffés post-hoc multiple comparisons technique was used to determine which functional disciplines differed from one another in respect of Scale 2. The results are given in Table 13. It is clear that Human Resources differs statistically significantly from Sales, the mean score of Sales for Scale 2 being higher than that of Human Resources.

Next, Dunnett's post-hoc multiple comparisons technique was used to determine which functional disciplines differed from one another in respect of Scales 3 and 6. In respect of Scale 3 no statistically significant differences between the groups were found (see Table 14). Finally, in respect of Scale 6 it appears that Finance differs statistically significantly from Sales, the mean score of Sales being higher than that of Finance (see Table 14). This is shown in Table 14. Hypothesis 3 is therefore only partially supported.

TABLE 14

DUNNETT'S POST-HOC MULTIPLE COMPARISONS: COMPARISON OF THE MEANS OF THE VARIOUS"FUNCTIONAL DISCIPLINES” IN RESPECT OF SCALES 3 AND 6 OF THE LSPQ

\begin{tabular}{llc}
\hline \multicolumn{1}{c}{ VARIABLE } & SCALE 3 & SCALE 6 \\
\hline Z 1 - H R & 82,75 & 74,19 \\
I DISTRIBUTION & 79,27 & 76,86 \\
I & 76,43 & 73,36 \\
4- FINANCE & 77,95 & 78,61 \\
5- MAR KETING & 78,30 & 73,28 \\
6- PRODUCTION & 76,80 & 74,29 \\
7-RISK CONTROL & 75,30 & 72,77 \\
8- SALES & 81,84 & 78,78
\end{tabular}

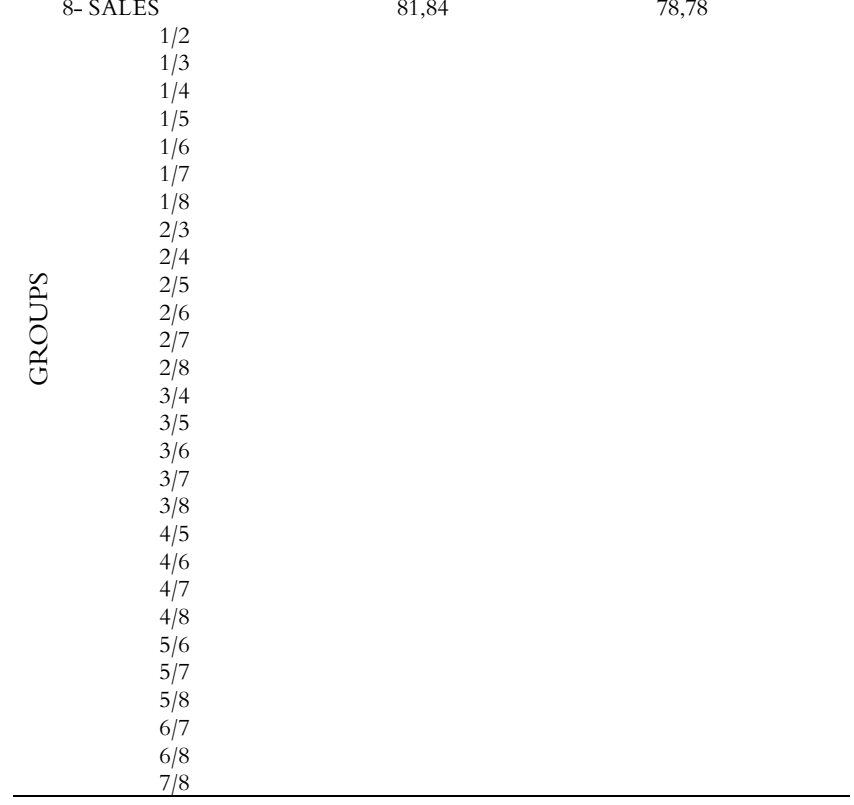

$\star_{p}=0,05$ 


\section{DISCUSSION}

At face value, learning styles and learning style instruments, and in particular the LSI (85), are appealing to people from business. Many researchers, however, have not endorsed the LSI (85) owing to its poor psychometric properties resulting mainly from its ipsative nature.

The 136 items written for the LSPQ were subjected to a factor analysis, resulting in six clearly defined factors. Next, six scales were constructed corresponding to the six factors that had been identified. These scales yielded reliabilities ranging from 0,809 to 0,939 . The six scales that emerged were identified as Scale 1: learning through reasoning, Scale 2: learning through observing, Scale 3: learning through exploring alternatives, Scale 4: learning through relying on a sound basis of fact and theory, Scale 5: learning through practising new skills and Scale 6: learning through considering all facts at hand.

From the second-order factor analysis that was done on the six scales, it is clear that there is a single second-order factor underlying the six scales, with five of the scales having substantial loadings on the second-order factor, but with Scale 2 having a very low commonality. Furthermore, it has transpired that Scale 2 has a high specificity $(0,714)$, i.e. it relates to a different kind of learning than the other five scales. From the content, it is apparent that Scale 2 relates to relatively simple forms of learning, whereas the other five scales relate to more complex forms of learning, requiring higher levels of insight. It is also interesting to note that Scale 4, learning through relying on a sound basis of fact and theory, has a negative loading on this factor, indicating that people with high scores on this scale tend to have lower scores on the rest.

On the surface it appears that there is a connection between the two bipolar dimensions of Kolb and the new scales of the LSPQ. It appears that there is a connection between Scale 4 (learning through relying on a sound basis of fact and theory) and Scale 6 (learning through considering all facts at hand) and the dimensions of abstract conceptualisation and concrete experience. There also appears to be a connection between Scale 2 (learning through observing) and Scale 5 (learning through practising new skills) and the dimensions of reflective observation and active experimentation. Scale 1 (learning through reasoning) and Scale 3 (learning through exploring alternatives) seem to be new and unique. It appears that Scales 1 and 3 are related to higher-order learning involving thinking processes instead of practical processes. The present study partially confirms the findings of Merrit and Marshall (1984) and Geiger et al. (1993). Merrit and Marshall's findings suggest that the normative form of the LSI is consistent with the learning style model proposed by Kolb. Geiger et al. (1993) found that their factor analysis did not support the existence of any bipolar dimensions, but did support the four separate learning styles. The present study also found support for four separate learning styles. However, it also identified two additional scales relating to higher-order learning. This was established by including more learning modes than the LSI (85).

As far as the ancillary aims are concerned, it was found that the mean score of the women in respect of Scale 5 (relating to learning through practising new skills) is higher than that of men. The present study thus partially confirms the findings of Severiens and Ten Dam (1997), who found that men and women prefer different learning styles, and that men show a greater preference for the abstract conceptualisation learning mode. The results are contrary to the findings of Wilson (1996), namely that women prefer not to be actively involved in the learning situation.

As far as the learning style preferences of the various academic groups are concerned, it was found that there are statistically significant differences in respect of Scales 1, 2 and 3. As far as Scale 1 is concerned, it appears that people with Grade 12 or equivalent qualifications have lower mean scores than people with technicon diplomas and post-graduate degrees/diplomas, indicating that the groups with technicon diplomas and postgraduate degrees/diplomas prefer learning of a higher-order. In respect of Scale 2, it appears that people with Grade 12 or equivalent qualifications have higher mean scores than people with bachelor's degrees and post-graduate degrees/diplomas, indicating that the group with Grade 12 or equivalent qualifications prefers learning of a lower complexity. Also the group with technicon diplomas has a higher mean score on Scale 2 than the group with bachelor's degrees and post-graduate degrees/diplomas, indicating that the group with technicon diplomas prefers learning of a lower complexity. In respect of Scale 3, it appears that people with Grade 12 or equivalent qualifications have a lower mean score than people with post-graduate degrees/diplomas, indicating that the group with post-graduate degrees/diplomas prefers learning of a higher-order. The present study thus partially confirms the findings of Kolb (1984), namely that people with different academic qualifications prefer different learning styles. In this study it appears that the group with Grade 12 or equivalent qualifications differs from the other academic groups. It appears that they prefer learning of a lower complexity.

Differences in respect of the learning style preferences of the various functional disciplines are reflected in statistically significant differences on Scales 2 and 6. In respect of Scale 2, it appears that people from Human Resources have a lower mean score than people from Sales, indicating that people from Sales prefer learning of a lower complexity. In respect of Scale 6, it appears that people from Finance have a lower mean score than people from Sales, indicating that people from Sales prefer learning of a more concrete nature.

In conclusion, the present study opens up new research possibilities, for instance understanding and finding the correct balance in responding to the generic learning style preferences of teams and individuals when conducting training. Although the focus of this study was on the cognitive aspects of learning, the value of the affective-social aspects of learning should not be overlooked and should be explored in future studies. The promising psychometric properties of the LSPQ should encourage other researchers to actively explore the validity of the various scales that were obtained.

\section{REFERENCES}

Abernathy, D. (1999). Leading-edge learning: Two views. Training \& Development, 53 (3), 40-42.

Allison, C.W. \& Hayes, J. (1988). The Learning Style Questionnaire: An alternative to Kolb's inventory. Journal of Management Studies, 25, 269-281.

Chi-Ching, Y. \& Moi, L. (1994). Learning styles and their implications for cross-cultural management in Singapore. Journal of Social Psychology, 134,596-600.

Cornwell, J.M. \& Manfredo, P.A. (1994). Kolb's learning style theory revisited. Educational and Psychological Measurement, 54, 317-327.

De Klerk, J. (1993). The connection of apprentices' learning styles, learning approaches, self-concept and academic achievement. Unpublished master's dissertation, University of Pretoria, Pretoria.

Dibella, A.J., Nevis, E.C. \& Gould, J.M. (1996). Understanding organisational learning capability. Journal of Management, 33, $361-379$.

Dubois, D.D. (1993). Competency-based performance improvement. Amherst, MA: HRD Press.

Ellinger, A.D., Watkins, K.E. \& Bostrom, R.P. (1999). Managers as facilitators of learning in learning organisations. Human Resource Development Quarterly, 10, 105-125.

Ferrell, B.G. (1983). A factor analysis comparison of four learning styles instruments. Journal of Educational Psychology, 75, 33-39.

Freedman, R. \& Stumpf, S. (1980). Learning style theory: Less than meets the eye. Academy of Management Review, 5, 445447.

Geiger, M.A., Boyle, E.J. \& Pinto, J.K. (1992). A factor analysis of Kolb's revised learning style inventory. Educational and Psychological Measurement, 52, 753-759.

Geiger, M.A., Boyle, E.J. \& Pinto, J.K. (1993). An examination of 
ipsative and normative versions of Kolb's revised Learning Styles Inventory. Educational and Psychological Measurement, 53, 717-726.

Heymans, B.S. (1988). The formation of an individualised management development model based on learning styles in a South African company. Unpublished master's dissertation, University of the Witwatersrand, Johannesburg.

Hickson, J. (1996). Gender related learning style patterns of middle school pupils. School Psychology International, 17, 59-70.

Honey, P. \& Mumford, A. (1982). The manual of learning styles. Maidenhead: Honey.

Honey, P. \& Mumford, A. (1995). Capitalizing on your learning style (3rd ed.). Carmarthen, Dyfed: Management Learning Resources, Ltd.

Hong, E. \& Suh, B.K. (1995). An analysis of change in KoreanAmerican and Korean students' learning styles. Psychological Reports, 76, 691-699.

Jonassen, D.A. \& Garabowski, B.L. (1993). Handbook of individual differences, learning, and instruction. Hillsdale, NJ: Lawrence Erlbaum.

Kaiser, H.F. (1961). A note on Guttman's lower bound for the number of common factors. British Journal of Statistical Psychology, 14, 1 .

Kolb, D.A. (1976). Learning style inventory. Technical Manual. Boston, MA: McBer.

Kolb, D.A. (1981). Experiential learning theory and the learning style inventory: A reply to Freedman and Stumpf. Academy of Management Review, 6, 289-296.

Kolb, D.A. (1984). Experiential learning. Englewood Cliffs, NJ: Prentice-Hall.

Kolb, D.A. (1985). Learning Style Inventory. Self-scoring Inventory and Interpretation Booklet. Boston, MA: McBer.

Kolb, D.A. (1995). Learning Style Inventory. Technical specifications. Boston, MA: McBer.

Loo, R. (1999). Confirming factor analyses of Kolb's learning style inventory. British Journal of Educational Psychology, 69, 213-219.

McCarthy, B. (1987). The 4 mat system. Barrington, IL: Excel.

Merrit, S.L. \& Marshall, J.C. (1984). Reliability and construct validity of ipsative and normative forms of the learning style inventory. Educational and Psychological Measurement, 44, 463-472.
Newstrom, J.W. \& Legnick-Hall, M.L. (1991). One size does not fit all. Training \& Development, 45, 43 - 48.

Pedler, M. \& Aspinwall, K. (1998). A concise guide to the learning organisation. London: Lemos \& Crane.

Prokesch, S.E. (1997). Unleashing the power of learning. Harvard Business Review, 75, 146-168.

Reynolds, M. (1997). Learning styles: A critique. Management Learning, 28, 115-133.

Schepers, J.M. (1992). Toetskonstruksie: Teorie en praktyk. Johannesburg: RAU Press.

Senge, P., Roberts, C., Ross, R.B., Smith, B.J. \& Kleiner, A. (1994). The fifth discipline fieldbook. New York: Doubleday.

Senge, P., Kleiner, A., Roberts, C., Ross, R.B., Roth, G. \& Smith, B.J (1999). The dance of change. New York: Doubleday.

Senge, P. (1999). Why organisations still aren't learning. Training $\mathcal{E}$ Development, 36, 40-49.

Severiens, S. \& Ten Dam, G. (1997). Gender and gender identity differences in learning styles. Educational Psychology, 17, 79-93.

Slaat, A., Lodewijks, H.G.L.C. \& Van der Saden, J.M.M. (1999). Learning styles in secondary vocational institutions. Learning and Instruction, 9, 475-492.

Smedley, L.C. (1987). Chemists as learners. Journal of Chemical Education, 64, 321-323.

Stuart, P. (1992). New direction in training individuals. Personnel Journal, 71, 86-94.

Van Wyk, B.J. (1992). Cognitive learning styles of black teacher students. Unpublished master's dissertation, University of Port Elizabeth, Port Elizabeth.

Verses, J.G., Sims, R.R. \& Locklear,T.S. (1991). Improving the reliability of Kolb's revised Learning Style Inventory. Educational and Psychological Measurement, 51, 144-150.

Willcoxson, L. \& Prosser, M. (1996). Kolb's Learning Style Inventory (1985): Review and further study of validity and reliability. British Journal of Psychology, 66, 247-257.

Wilson, V. (1996). Scholars, active learners, and social butterflies: preferred learning styles of high school biology I students. Paper presented at the annual meeting of the Mid-South Educational Research Association. Tuscaloosa, AL. 